\title{
Technology for the Identification of Suspicious Contracts Involving Sustainable Groups of Suppliers in Public Procurements
}

\section{Domashova D. V., Lenchinskaja K. O., and Pisarchik E. E.}

National Research Nuclear University MEPhI (Moscow Engineering Physics Institute), Kashirskoe shosse 31, Moscow, 115409, Russia

\section{Abstract}

The paper discusses the problems that customers may encounter while conducting public procurement, namely, possible prior collusion between bidders aimed at winning the contract at the highest possible price.

The objective of the study is to develop a technology for automated detection of sustainable groups of pipe suppliers in public procurements, and also to develop an

Corresponding Author:

Lenchinskaja K. 0.

lenkseniya@yandex.ru

Received: 11 December 2017

Accepted: 20 January 2018

Published: 13 February 2018

Publishing services provided by

Knowledge E

(c) Domashova D. V. et al. This article is distributed under the

terms of the Creative Commons

Attribution License, which

permits unrestricted use and redistribution provided that the original author and source are credited.

Selection and Peer-review under the responsibility of the FinTech and RegTech: Possibilities, Threats and Risks of Financial Technologies Conference Committee. algorithm that would allow to identify possible collusion between future procurement participants.

Presumed indicators of collusion between suppliers are formulated, a technology for identifying a sustainable supplier group is described, an algorithm to assess the possibility of affiliated suppliers participating in the current tender is developed.

Keywords: public procurement, collusion of suppliers

\section{Introduction}

The state order is an order to supply goods, perform work, provide services at the expense of the federal budget, budgets of the constituent entities of the Russian Federation, local (municipal) budgets and extra-budgetary sources of funding. Growing portion of tenders in public administration, increasing number of auctions, annual increase of financing are accompanied by related problems that are becoming more acute: ineffective budget spendings, negligence in organizing tenders, unprepared personnel, thefts, fraud [1].

One of the most common factors contributing to contract overpricing is a prior collusion between bidders which is aimed at winning the contract at the highest possible price.

\section{G OPEN ACCESS}




\section{Materials and methods}

The original data about piping procurement was taken from the Unified Information System (UIS) of Government procurement [2]. The data includes information on procurement planning, tenders, contracts awarded and the results of contracts implementation. The data was downloaded using the automated Site Parser program to the SQL Developer integrated processing environment with the ability to administer databases.

An attempt was made to identify the sustainable groups of vendors that have often taken part in the tenders in whole multitude of piping public procurements. This task was resolved by a priori algorithm (Assoc Build) that identifies the presence of constants within a single transaction [3]. This algorithm allows to identify the vendors who have frequently participated jointly in the tenders. The output of this algorithm provides "sustainable supplier groups", which are one of the first signs of a suspicious procurement.

\section{Findings}

As a result, six sustainable groups containing four suppliers were identified. The groups were defined according to the algorithm indicators, such as reliability and support. Support shows the lot percentage of the group, depending on the total number of lots. Reliability indicates the probability that a fourth member will be added to the sustainable group of three members. Support averaged $2.25 \%$, with reliability of at least $90 \%$. Whereas authentic data was used in the survey, the paper has been sanitized for all vendor information. The composition of the sustainable vendor groups is presented in Table 1.

There are eight unique providers from the identified groups: Company 1, Company 2, Company 3, Company 4, Company 5, Company 6, Company 7, Company 8.

A thorough analysis of the tenders, in which the identified vendor groups took part, was further carried out. The following indicators were calculated based on the SQL queries: number of lots in the group, percent of member wins within a group, number of group wins, average sum of group contracts, average number of participants outside the group, average lot price inside the group, average lot price outside the group, average savings per participant lot, average savings per lot in group and other. Some of them are presented in Table 2. 
TABLE 1: Composition of sustainable supplier groups.

\begin{tabular}{|c|c|c|}
\hline Group number & $\begin{array}{c}\text { Sustainable group } \\
\text { member number }\end{array}$ & $\begin{array}{c}\text { Members of a sustainable } \\
\text { group }\end{array}$ \\
\hline \multirow[t]{4}{*}{1} & 1.1 & Company 1 \\
\hline & 1.2 & Company 2 \\
\hline & 1.3 & Company 8 \\
\hline & 1.4 & Company 4 \\
\hline \multirow[t]{4}{*}{2} & 2.1 & Company 8 \\
\hline & 2.2 & Company 3 \\
\hline & 2.3 & Company 2 \\
\hline & 2.4 & Company 4 \\
\hline \multirow[t]{4}{*}{3} & 3.1 & Company 1 \\
\hline & 3.2 & Company 3 \\
\hline & 3.3 & Company 8 \\
\hline & 3.4 & Company 4 \\
\hline \multirow[t]{4}{*}{4} & 4.1 & Company 8 \\
\hline & 4.2 & Company 3 \\
\hline & $4 \cdot 3$ & Company 6 \\
\hline & 4.4 & Company 4 \\
\hline \multirow[t]{4}{*}{5} & 5.1 & Company 1 \\
\hline & 5.2 & Company 6 \\
\hline & $5 \cdot 3$ & Company 8 \\
\hline & 5.4 & Company 3 \\
\hline \multirow[t]{4}{*}{6} & 6.1 & Company 5 \\
\hline & 6.2 & Company 7 \\
\hline & 6.3 & Company 1 \\
\hline & 6.4 & Company 2 \\
\hline
\end{tabular}

It's worth noticing that the percentage of wins in the group is roughly the same, and the average percentage of lot savings is rather low.

Next, a tender study where unique suppliers have participated (without other group members) is conducted. The results of the study are shown in Table 3.

It can be concluded that if the suppliers participate in the tender outside sustainable groups, their average lot savings rate is generally considerably higher than in the group 
TABLE 2: Characteristics of sustainable suppliers groups.

\begin{tabular}{|c|c|c|c|c|c|c|}
\hline $\begin{array}{l}\text { Group } \\
\text { number }\end{array}$ & $\begin{array}{c}\text { Sustainable } \\
\text { group } \\
\text { member } \\
\text { number }\end{array}$ & $\begin{array}{l}\text { Percent of } \\
\text { member } \\
\text { wins within } \\
\text { a group }\end{array}$ & $\begin{array}{c}\text { Average } \\
\text { savings per } \\
\text { participant } \\
\text { lot }\end{array}$ & $\begin{array}{l}\text { Average } \\
\text { savings per } \\
\text { lot in group }\end{array}$ & $\begin{array}{c}\text { Percentage } \\
\text { of group } \\
\text { wins }\end{array}$ & $\begin{array}{l}\text { Sum of group } \\
\text { contracts }\end{array}$ \\
\hline \multirow[t]{4}{*}{1} & 1.1 & $21,95 \%$ & $0,48 \%$ & $0,46 \%$ & $81,71 \%$ & $\begin{array}{c}232616760 \\
074,80 \mp\end{array}$ \\
\hline & 1.2 & $15,85 \%$ & $0,37 \%$ & & & \\
\hline & 1.3 & $21,95 \%$ & $0,45 \%$ & & & \\
\hline & 1.4 & $21,95 \%$ & $0,54 \%$ & & & \\
\hline \multirow[t]{4}{*}{2} & 2.1 & $20,99 \%$ & $0,45 \%$ & $0,43 \%$ & $79,01 \%$ & $\begin{array}{c}206624333 \\
388,10 \mp\end{array}$ \\
\hline & 2.2 & $22,22 \%$ & $0,36 \%$ & & & \\
\hline & 2.3 & $14,81 \%$ & $0,37 \%$ & & & \\
\hline & 2.4 & $20,99 \%$ & $0,54 \%$ & & & \\
\hline \multirow[t]{4}{*}{3} & 3.1 & $21,77 \%$ & $0,39 \%$ & $0,40 \%$ & $84,68 \%$ & $\begin{array}{c}352866580 \\
557,00 ₹\end{array}$ \\
\hline & 3.2 & $17,74 \%$ & $0,42 \%$ & & & \\
\hline & 3.3 & $20,97 \%$ & $0,38 \%$ & & & \\
\hline & 3.4 & $24,19 \%$ & $0,41 \%$ & & & \\
\hline \multirow[t]{4}{*}{4} & 4.1 & $8,06 \%$ & $0,10 \%$ & $0,11 \%$ & $80,00 \%$ & $\begin{array}{c}89324774 \\
948,00 P\end{array}$ \\
\hline & 4.2 & $0,00 \%$ & - & & & \\
\hline & 4.3 & $8,06 \%$ & $0,11 \%$ & & & \\
\hline & 4.4 & $9,68 \%$ & $0,11 \%$ & & & \\
\hline \multirow[t]{4}{*}{5} & 5.1 & $8,06 \%$ & $0,10 \%$ & $0,10 \%$ & $72,22 \%$ & $\begin{array}{c}76812588436,20 \\
P\end{array}$ \\
\hline & 5.2 & $5,65 \%$ & $0,11 \%$ & & & \\
\hline & 5.3 & $7,26 \%$ & $0,10 \%$ & & & \\
\hline & 5.4 & $0,00 \%$ & & & & \\
\hline \multirow[t]{4}{*}{6} & 6.1 & $11,29 \%$ & $12,34 \%$ & $10,50 \%$ & $90,38 \%$ & $\begin{array}{c}65733708550,17 \\
P\end{array}$ \\
\hline & 6.2 & $8,87 \%$ & $10,61 \%$ & & & \\
\hline & 6.3 & $6,45 \%$ & $9,77 \%$ & & & \\
\hline & 6.4 & $11,29 \%$ & $9,29 \%$ & & & \\
\hline
\end{tabular}


TABLE 3: Characteristics of unique suppliers.

\begin{tabular}{l} 
Name \\
Company 1 \\
\hline Company 2 \\
\hline Company 3 \\
\hline Company 4 \\
\hline Company 5 \\
\hline Company 6 \\
Company 7 \\
Company 8
\end{tabular}

\begin{tabular}{l} 
Average percentage of lot savings \\
when participating outside groups \\
$\qquad \begin{array}{c}14,95 \% \\
10,38 \% \\
0,36 \% \\
13,84 \% \\
10,62 \% \\
16,05 \% \\
17,61 \% \\
25,12 \%\end{array}$ \\
\hline
\end{tabular}

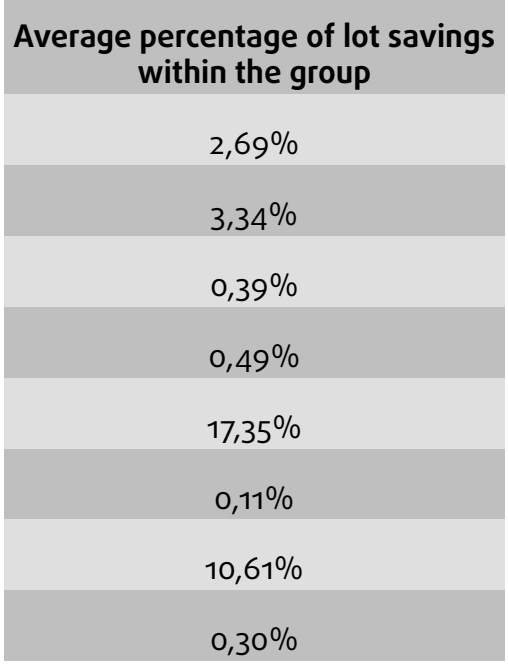

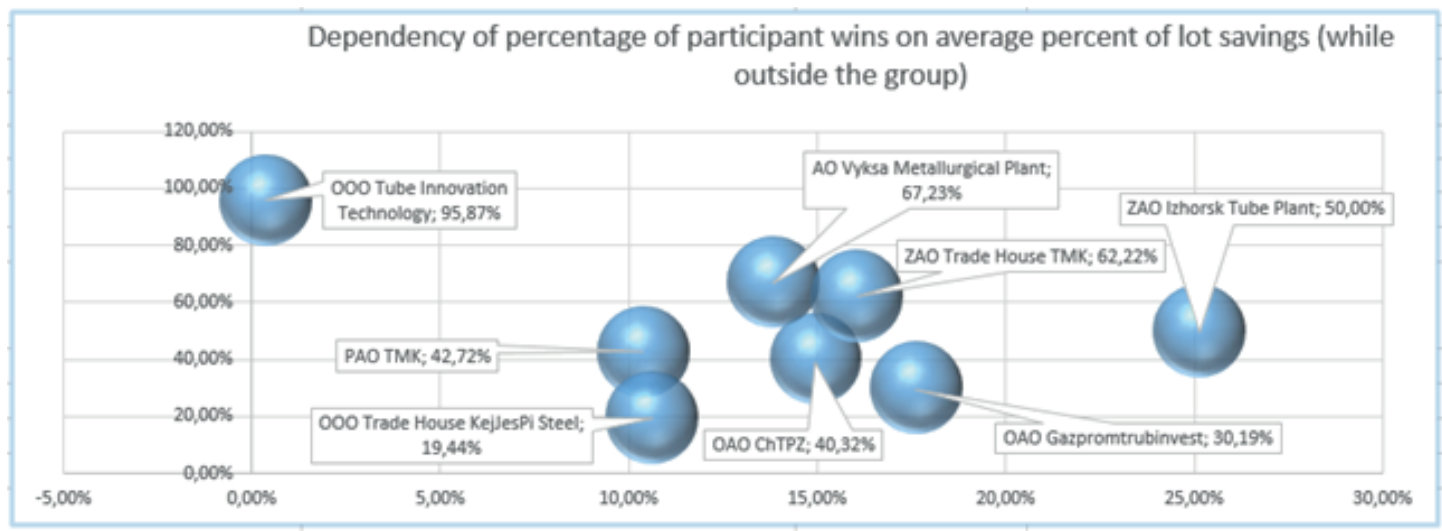

Figure 1: Dependency of percentage of participant wins on average percent of lot savings (while outside the group).

and is close to the average rate of savings for the entire sample $-16.91 \%$. Company 3 and Company 5.

For unique suppliers when they participate in tenders outside the groups and inside the groups, the following dependencies are being explored: the contract amounts of the lot savings percentage and the percentage of wins as a percentage of lot savings (Fig. 1 - Fig. 4).

It can be seen that, when a sustainable group member is outside the group, there is a wide variation in the percentage of wins and the average percentage of lot savings. Market leaders are actively victorious and average savings rates are close to the average percentage savings for the entire sample (16.91\%). With joint participation, there is a clear accumulation of suppliers on the left side of the schedule, which shows close percentages of wins and a low percentage of lot savings. The exception was Company 7 and Company 5. 


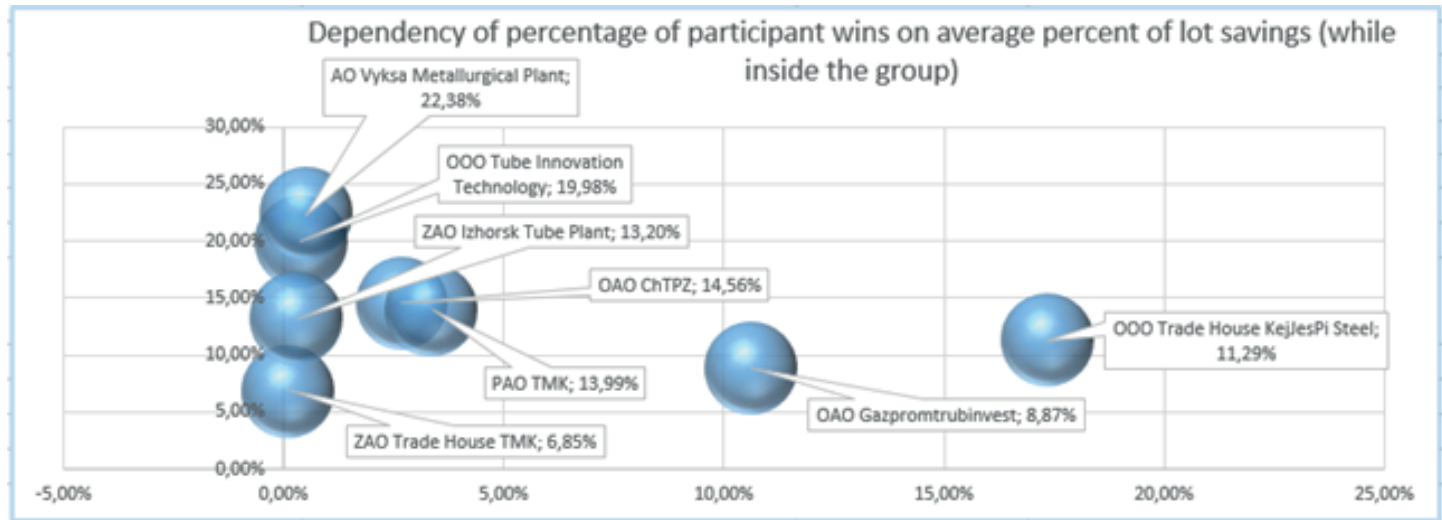

Figure 2: Dependency of percentage of participant wins on average percent of lot savings (while inside the group).

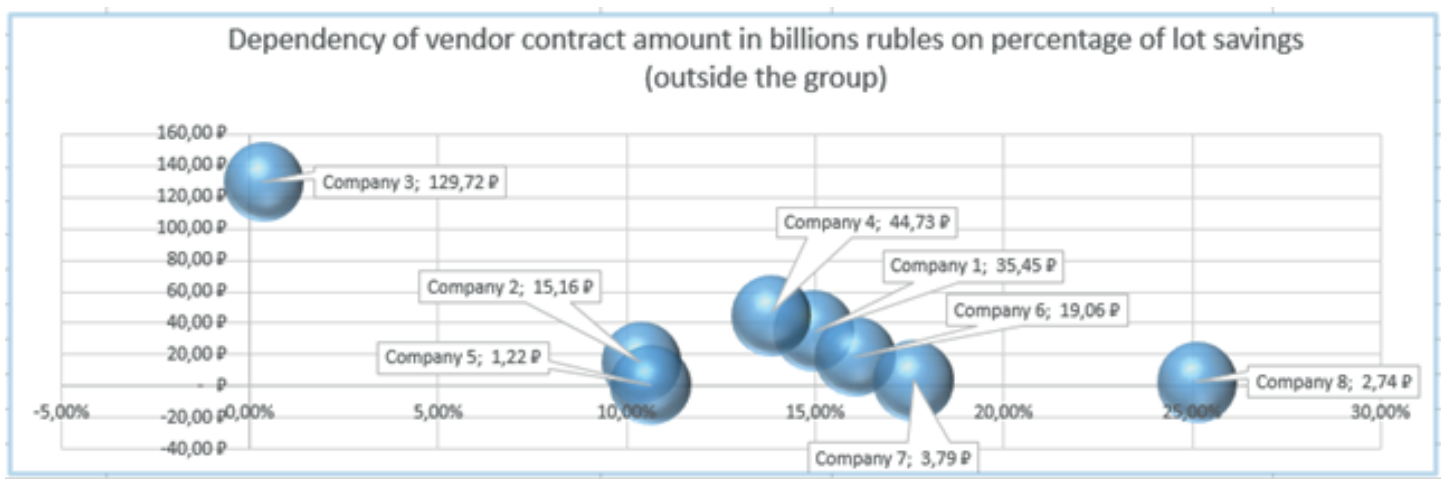

Figure 3: Dependency of vendor contract amount in billions rubles on percentage of lot savings (outside the group).

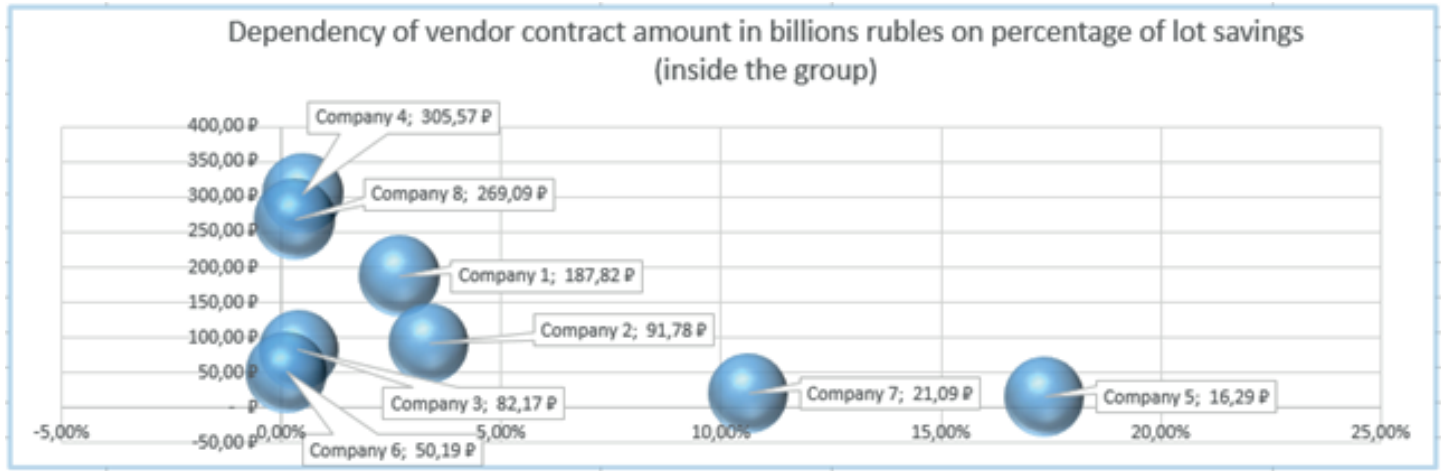

Figure 4: Dependency of vendor contract amount in billions rubles on percentage of lot savings (inside the group).

The dependencies shown in Figures 3 and 4 were also examined.

By comparing the two dependencies, it can be seen that sustainable group members won higher contracts when they were inside the group, than when they were outside the groups. This may have been due not only to the low percentage of savings but to the specificity of the purchase. 


\section{Discussion}

The following are the indicators for assessing the level of suspicion of procurement for overestimating the contract price in the conduct of procurement in the pipe industry based on some characteristics (Table 4 ) of or the sustained groups of suppliers, who often jointly participate in public procurements, identified using A Priori Algorithm.

TABLE 4: Characteristics of procurement.

Characteristic name
The minimum average percentage of lot savings among the identified
groups;
Average savings per lot in group
The maximum average percentage of lot savings among the identified
groups;
Average lot savings per sample ( 3574 lot)
Average of the extent of variation in the percentage of wins among
groups;
Average percentage of lot savings within the group
Average rate of savings by lot suppliers (outside the group)

\begin{tabular}{c} 
Value \\
$0,10 \%$ \\
$2,00 \%$ \\
$10,50 \%$ \\
\hline $16,91 \%$ \\
$7,09 \%$ \\
\hline$\%$ Ecl_group $=4.41 \%$ \\
\hline \% Ecl_own $=13,62 \%$
\end{tabular}

Indicator 1-Low value of average lot savings.

Calculation of the average savings per lot (\% $\mathrm{ECL})$ in the group.

The following degrees of suspicion of a procurement can be defined:

- High degree at $0.10 \%<=\% \mathrm{ECL}<2.00 \%$;

- The average degree of $2.00 \%<=\% \mathrm{ECL}<10.50 \%$;

- Low degree of $10.50 \%<=\% \mathrm{ECL}<=16.91 \%$;

Indicator 2-Roughly the same percentage of wins within a group.

Calculation of the percentage of member wins within the group (\% Vic).

The difference in range from $0 \%<=d \%$ Vic $<=7.09 \%$ indicates a high degree of suspicion of purchasing.

Indicator 3-A fairly large difference between the average percentage of lot savings for identified group suppliers, with independent participation, and the average rate of savings of lot suppliers with participation in sustainable groups.

Calculation of the average lot savings of the identified group providers with independent participation (\% Ecl_own). 
Calculation of the average savings for lot vendors when participating in groups (\% ecl_group).

The following degrees of suspicion of a procurement can defined:

- High degree at $\frac{\% \text { Ecl_group }}{\% \text { Ecl_own }}<0.32$;

- Average degree at $0.64 ; 0,32<=\frac{\% \text { Ecl_group }}{\% \text { Ecl_own }}<$

- Low degree at $0.64<\frac{\% \text { Ecl_group }}{\% \text { Ecl_own }} \leq 1=$.

The following algorithm can further determine the degree of suspicion of a particular future tender for possible overpricing, based on a preliminary study of the businesses operating sample in a certain Industry.

For the selected industry (goods or services) based on the above, the relevant procurement data should be prepared:

- Generate a list of members of sustainable groups (algorithm A Priori);

- Calculate the characteristics of unique providers (Table 3);

- Calculate the characteristics of sustainable groups (Table 2);

- Calculate the boundary values for the signs of collusion in a given sample (Table 4).

The scheme of the algorithm for detecting suspicious purchases for minor savings in the contract price with the participation of a sustained group of vendors is presented in Figure 5.

The algorithm is designed to identify the number of bidders affiliated with the multitude of unique members of the groups in the pertinent procurement sphere, and then to calculate the indicators testifying to the degree of suspicion of the procurement. However, the degree of suspicion depends on the number of unique team members in the tender under examination.

This procedure can form the basis of an automated technology for detecting suspicious procurements so that the customer's strategy for purchasing is built.

\section{Conclusion}

In the course of the study, indicators of suspicious procurement were identified, a technology to identify them and an algorithm to identify possible collusion among participants in future procurement were developed. 


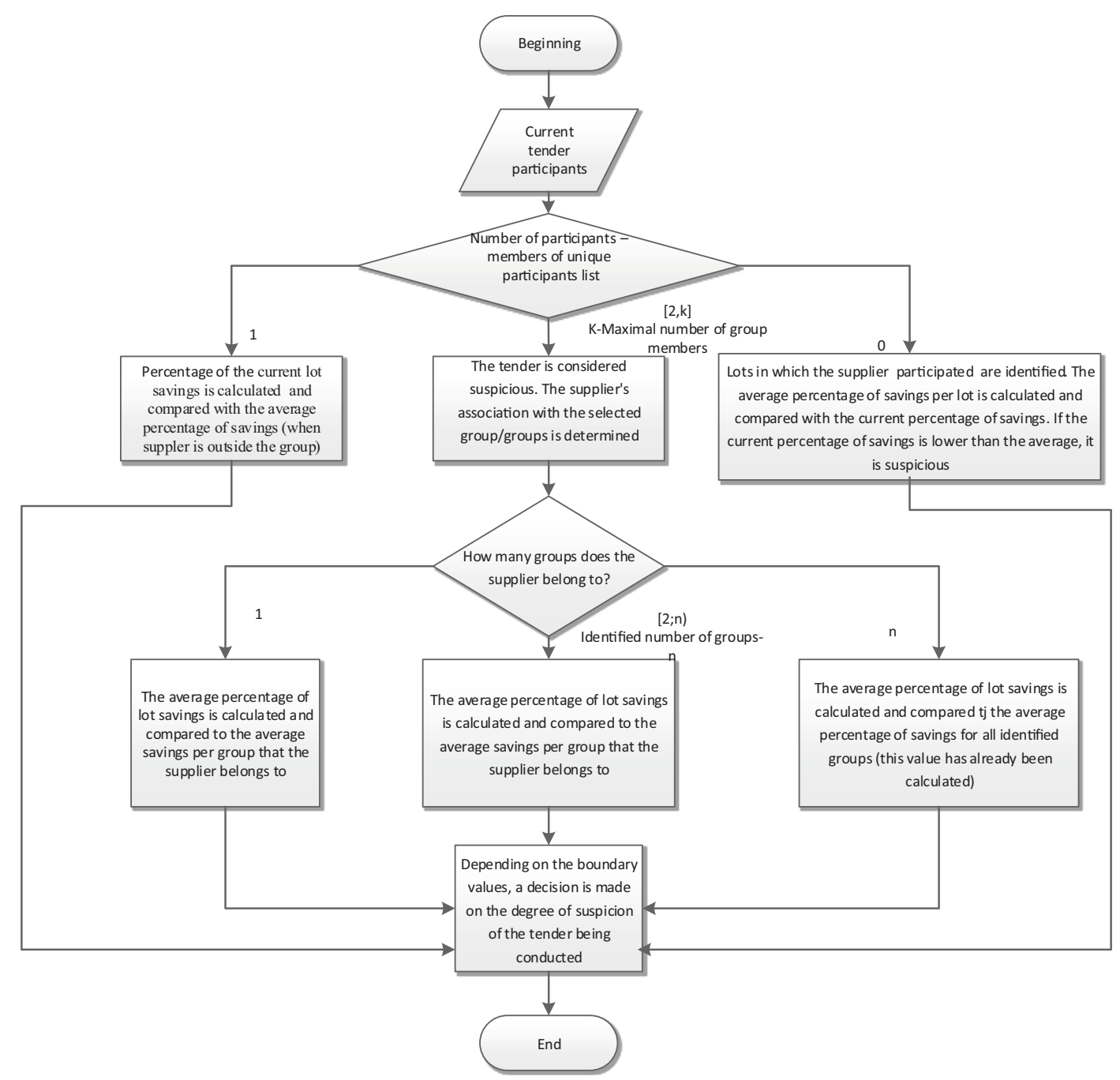

Figure 5: Diagram of the algorithm for detecting suspicious procurements.

The results of the study can be used both to develop new regulatory and supervisory approaches aimed at adequate risk management in financial institutions as well as to government customers to prevent fraud and inefficient use of budgetary resources.

\section{Acknowledgements}

This work was supported by Competitiveness Growth Program of the Federal Autonomous Educational Institution of Higher Education National Research Nuclear University MEPhl (Moscow Engineering Physics Institute).

\section{References}

[1] Site EAG [Electronic resource] access mode: -http://www.eurasiangroup.org/ru/typology 
[2] Official procurement portal [electronic resource] access mode: zakupki.gov.ru

[3] Web site on scalable algorithm A Priori [electronic resource] access mode: Https : //basegroup.ru/community/articles/apriori 